\title{
A crítica da governação neoliberal: O Fórum Social Mundial como política e legalidade cosmopolita subalterna
}

The critique of neoliberal governance: The World Social Forum as subaltern cosmopolitan politics and legality

La critique de la gouvernance néo-libérale : le Forum Social Mondial en tant que politique et légalité cosmopolite subalterne

Boaventura de Sousa Santos

\section{OpenEdition}

\section{Journals}

Edição electrónica

URL: http://journals.openedition.org/rccs/979

DOI: $10.4000 /$ rccs. 979

ISSN: 2182-7435

\section{Editora}

Centro de Estudos Sociais da Universidade de Coimbra

Edição impressa

Data de publição: 1 Outubro 2005

Paginação: 07-44

ISSN: 0254-1106

Refêrencia eletrónica

Boaventura de Sousa Santos, « A crítica da governação neoliberal: O Fórum Social Mundial como política e legalidade cosmopolita subalterna », Revista Crítica de Ciências Sociais [Online], 72 | 2005, colocado online no dia 01 outubro 2012, criado a 19 abril 2019. URL : http://journals.openedition.org/ rccs/979; DOI : 10.4000/rccs.979 


\title{
A crítica da governação neoliberal: O Fórum Social Mundial como política e legalidade cosmopolita subalterna'
}

\begin{abstract}
A governação é hoje apresentada como um novo paradigma de regulação social que veio suplantar o paradigma anteriormente em vigor assente no conflito social e no papel privilegiado do Estado, enquanto ente soberano, para regular esse conflito por via do poder de comando e de coerção ao seu dispor. Neste artigo faço uma crítica radical do novo paradigma, concebendo-o como a matriz regulatória do neoliberalismo, entendido como a nova versão do capitalismo de laissez faire. Centrada na questão da governabilidade, esta matriz regulatória pressupõe uma política de direito e de direitos que tende a agravar a crise da legitimidade do Estado. Algumas das facetas da governação podem ser encontradas no movimento global de resistência contra a globalização neoliberal que tem hoje a sua melhor expressão no Fórum Social Mundial. Ao contrário da governação hegemónica, este movimento assenta na ideia de conflito e da luta contra a exclusão social, o que se torna manifesto nas concepções e políticas de direito que adopta.
\end{abstract}

\section{Introdução}

Defendi, noutro local, que existem duas formas de globalização: a globalização neoliberal e aquilo a que eu chamo uma globalização contra-hegemónica, que desde há algum tempo se vem opondo à primeira (Santos, 2002: capítulos 5, 9). Designo por globalização contra-hegemónica o conjunto vasto de redes, iniciativas, organizações e movimentos que lutam contra as consequências económicas, sociais e políticas da globalização hegemónica e que se opõem às concepções de desenvolvimento mundial a esta subjacentes, ao mesmo tempo que propõem concepções alternativas.

A globalização contra-hegemónica centra-se nas lutas contra a exclusão social. Atendendo a que a exclusão social é sempre produto de relações de poder desiguais, a globalização contra-hegemónica é animada por um ethos redistributivo no sentido mais amplo da expressão, o qual implica a redistribuição de recursos materiais, sociais, políticos, culturais e simbólicos.

\footnotetext{
1 Pelos comentários a uma primeira versão deste texto, os meus agradecimentos a Celeste Benson, Arturo Escobar, Marc Galanter, Candido Grzybowszki, Joel Handler, António Martins, Paula Meneses, Moema Miranda, Walter Mignolo, Nelson Maldonado-Torres, Cesar Rodríguez-Garavito, Jorge Romano, Pedro Santana, Jai Sen, Ronen Shamir, David Sugarman, Teivo Teivonan, Virginia Vargas, Peter Waterman, Francisco Whitaker, Lucie White, e Bill Whitford.
} 
Neste sentido, a redistribuição baseia-se, simultaneamente, no princípio da igualdade e no princípio do reconhecimento da diferença. Em causa está a luta por trocas iguais e iguais relações de autoridade (mais do que relações de poder). Uma vez que as trocas e as relações de poder desiguais se cristalizam na política e no direito, a globalização contra-hegemónica desdobra-se em lutas políticas e lutas jurídicas orientadas pela ideia de que é possível pôr em causa as estruturas e as práticas político-jurídicas através de princípios político-jurídicos alternativos. A estes princípios alternativos e às lutas em sua defesa chamei política e legalidade cosmopolita subalterna (Santos, 2002: 465; 2003). Neles se inclui um vasto campo confrontacional de política e direito em que distingo dois processos fundamentais de globalização contra-hegemónica: a acção colectiva global, que opera através de redes transnacionais de ligações locais/nacionais/globais; e as lutas locais ou nacionais, cujo êxito induz a reprodução noutros lugares ou o funcionamento em rede com lutas paralelas em curso noutras paragens. No presente artigo, debruçar-me-ei sobre o primeiro processo, analisando a política e o direito corporizados pelo Fórum Social Mundial (FSM) e estabelecendo o contraste com a política e o direito neoliberais. Para tal, dividirei o artigo em três secções. Em primeiro lugar, debruçar-me-ei sobre algumas das inovações jurídicas trazidas pela globalização neoliberal, concretamente no que se refere à governação enquanto suposto modo de regulação social pós-estatal. Seguidamente, analisarei o FSM enquanto expressão da globalização contra-hegemónica dentro da qual estão em vias de ser forjadas uma política e uma legalidade cosmopolita subalterna. Por fim, estabelecerei um contraste explícito entre formas de política e de política de direito hegemónicas e contra-hegemónicas.

Antes de prosseguir, e dada a visão estreita do direito e da política que actualmente domina os estudos jurídicos, importa clarificar a concepção de direito e de política de que farei uso ao longo deste artigo. Subjacentes à globalização neoliberal e à globalização contra-hegemónica, encontram-se concepções diferentes de direito e de política do direito. Ambas, porém, exigem que se proceda a um alargamento radical daquilo que convencionalmente se entende por direito e política do direito. A meu ver, são precisos quatro alargamentos conceptuais para se captar a política do direito num contexto de globalização. O primeiro diz respeito ao âmbito das acções, lutas, ou disputas jurídicas. No contexto de globalizações conflituantes entre si, as práticas jurídicas colectivas aliam a mobilização política à mobilização jurídica, podendo esta envolver acções tanto legais como ilegais e não-legais ou a-legais. O segundo alargamento tem a ver com a escala. A política do direito tem de ser conceptualizada em três escalas 
distintas - a local, a nacional, e a global. $\mathrm{Na}$ maioria dos casos, todas as escalas envolvidas se interpenetram. As lutas de poder pela escala relevante do direito são, hoje em dia, travadas num contexto de predomínio crescente da escala global. O terceiro alargamento diz respeito ao saber jurídico e ao respectivo grau de especialização. A política do direito implica uma variedade de saberes jurídicos e um grau de especialização de que o saber jurídico profissional é apenas uma componente. Num campo jurídico cada vez mais fragmentado e trans-escalar e num contexto de predomínio crescente do saber económico neoliberal, é frequente saberes jurídicos rivais (local ou nacional $v s$ transnacional; profissional vs leigo; velha doutrina jurídica $v s$ concepções emergentes) colidirem entre si. Finalmente, a quarta dimensão de uma concepção alargada da política do direito é a dimensão temporal. Este alargamento temporal tem duas vertentes. O direito estatal moderno está sujeito à moldura temporal da acção do Estado (como, por exemplo, o tempo do processo judicial, o tempo do ciclo eleitoral e o tempo do processo legislativo e da burocracia). No entanto, a mobilização jurídica implica muitas vezes molduras temporais contrastantes. Por um lado, temos o tempo instantâneo do capital financeiro (para o qual o longo prazo são os próximos dez minutos). Por outro lado, temos a longue durée do capitalismo e do colonialismo, ou mesmo a duração mais longa de todas (um tempo glacial), que é a da deterioração ecológica ou da exaustão dos recursos naturais (como, por exemplo, nos conflitos jurídicos envolvendo os povos indígenas em luta contra as companhias petrolíferas a operar nos respectivos territórios [Rodríguez-Garavito e Arenas, 2005]). Sucede muitas vezes as batalhas jurídicas serem marcadas pela presença de concepções de tempo radicalmente diferentes, com os conflitos a serem travados num contexto em que a moldura temporal dominante parece aproximar-se cada vez mais do tempo instantâneo do capital financeiro. A segunda vertente diz respeito ao contraste entre o tempo linear que preside à lógica de desenvolvimento do Ocidente - assente numa concepção unilinear de desenvolvimento, segundo a qual diferentes passados convergem para um único futuro - e uma concepção pluralista de tempo assente na ideia de que existem vias alternativas de desenvolvimento e de que, por conseguinte, diferentes passados subjazem a diferentes presentes, podendo conduzir a diferentes futuros.

Tendo em mente uma tal reconceptualização, torna-se possível analisar os contornos do papel da política e do direito na globalização hegemónica e contra-hegemónica. E é nessa tarefa que me deterei de seguida. 


\section{A governação como legalidade neoliberal}

Desde que há testemunhos históricos escritos até 1975, o catálogo da Biblioteca do Museu Britânico regista 47 títulos contendo a palavra "governação" (governance). A partir de então, a palavra teve uma proliferação desenfreada em todas as disciplinas das ciências sociais. Essa presença avassaladora só encontra paralelo, durante o mesmo período, no termo "globalização". Esta convergência de trajectórias não é fruto do acaso. Como procurarei demonstrar, desde meados da década de 1990 que a governação se tornou a matriz política da globalização neoliberal. Chamo-lhe matriz porque se trata de uma estrutura basilar, ou de engaste, e simultaneamente de um ambiente fomentador de toda uma rede de ideias pragmáticas e de padrões de comportamento cooperativo, partilhados por um grupo de actores seleccionados e respectivos interesses; uma rede auto-activada, destinada a lidar com o caos num contexto em que nem a ordem normativa exercida do topo para a base e gerada a partir do exterior (comando estatal) nem o ordenamento participativo autónomo feito da base para o topo e não-pré-seleccionado (democracia participativa) estão disponíveis, ou, se estão disponíveis, não são desejáveis. Decisiva para esta matriz é a ideia de que ela se vê a si própria como sendo autogerada de uma forma cooperativa e, por isso, como sendo o mais inclusiva possível. Como qualquer outra matriz, ela assenta num princípio de selectividade e, como tal, no binómio inclusão/exclusão. Neste caso, contudo, os excluídos, em vez de estarem presentes como excluídos, estão completamente ausentes. A governação é, assim, uma matriz que alia a horizontalidade à verticalidade de uma maneira nova: ambas são autogeradas, aquela como omni-existente, esta como não-existente. Ela funciona por meio de uma falsa dialéctica entre governação e desgovernação, em que o segundo termo, em vez de infirmar a governação confrontando-a, mais não faz do que ratificá-la, devido a faltar-lhe ora o objecto, ora o agente.

Bob Jessop (1998) chama "paradigma da governação" a este fenómeno político-ideológico. Paradigma será talvez um conceito demasiado forte para caracterizar o fenómeno, especialmente se entendermos os paradigmas na formulação originariamente proposta por Kuhn (1970), ou seja, como concepções científicas universalmente reconhecidas e que, durante um certo período, proporcionam problemas-modelo e soluções-modelo para uma comunidade de cientistas. Considerando que são muitas e diversas as concepções de governação existentes, diferentemente posicionadas ao longo do espectro político, ${ }^{2}$ prefiro uma designação mais branda e mais estreita

\footnotetext{
${ }^{2}$ Existe uma vasta literatura alusiva à governação, podendo encontrar-se uma boa panorâmica em Rodríguez-Garavito (2005).
} 
- a matriz da governação. É possível, assim, discernir a matriz da governação e a multidão da governação. Deste modo, uma ideologia esquiva e uma prática que de um modo geral ainda não foi testada funcionam como um apelo vago, capaz de mobilizar cientistas sociais, decisores políticos e juristas com os mais variados perfis intelectuais e filiações políticas.

Faço uma distinção entre a matriz da governação e a multidão da governação porque, por mais vaga que seja, a matriz é menos heterogénea do que os grupos que dela se reclamam. Encontramo-nos num estádio de desenvolvimento do conceito de governação muito semelhante ao que se verificava com o conceito de globalização em meados da década de 1990, altura em que as práticas sociais ainda não permitiam discernir completamente as clivagens e contradições geradas pelos próprios processos de globalização. Nas páginas que se seguem procurarei responder a três perguntas: (1) como surgiu a governação, e porquê? (2) que significado político tem? e (3) há outras histórias da governação?

\subsection{Genealogia da governação}

Para entender o surgimento da matriz da governação, temos que recuar ao início da década de 1970, e concretamente ao movimento estudantil e à crise de legitimidade a que este deu origem. Como mostraram Jürgen Habermas (1982) e Claus Offe (1985), a crise adveio do questionamento radical do conteúdo tanto social como democrático do contrato social subjacente aos Estados sociais-democráticos após o fim da Segunda Guerra Mundial. Para o movimento estudantil - a que logo viriam juntar-se os movimentos feminista e ecológico -, o contrato social, ao contrário daquilo que aparentava, visava, de facto, excluir e não incluir. Excluía por completo grandes grupos sociais (como as minorias e os imigrantes) e questões sociais importantes (como a diversidade cultural e o ambiente), e incluía outros grupos, subordinando-os a formas de inclusão destituidoras de poder - como era o caso, muito flagrantemente, das mulheres. Por outro lado, tudo isto se tornara possível porque a democracia não conseguira cumprir a sua promessa de construção de sociedades livres e iguais. As ideias de soberania do povo e de participação popular haviam sido sequestradas por formas elitistas de governo democrático, graças à cumplicidade dos dois actores sociais historicamente encarregados da tarefa de aprofundar a democracia e de conduzir à emancipação social: os partidos operários e os sindicatos. Foi uma crise de legitimidade porque foi uma crise do governo baseado no consenso, dominando a contestação política em todo o Norte durante a primeira metade da década de 1970 (Monedero, 2003). 
O ponto de viragem deu-se em 1975, quando a Comissão Trilateral publicou o seu relatório sobre a crise da democracia, da autoria de Crozier, Huntington e Watanuki (1975). Segundo estes, a democracia estava, de facto, em crise. Não, porém, por haver democracia a menos, mas, pelo contrário, por haver democracia a mais. As democracias estavam em crise porque se encontravam sobrecarregadas com direitos e reivindicações e porque o contrato social, em vez de excluir, era demasiado inclusivo, devido precisamente às pressões sobre ele exercidas pelos actores sociais históricos atacados pelos estudantes (os partidos operários e os sindicatos). Com esta análise e o poder social por detrás dela, a crise do governo baseado no consenso (crise de legitimidade) transformou-se numa crise do governo tout court, e, com isto, a crise de legitimidade transformou-se em crise de governabilidade.

A natureza da contestação política viu-se, desta forma, profundamente alterada. O foco, antes centrado na incapacidade do Estado para fazer justiça aos novos movimentos sociais e às suas exigências, passou a centrar-se na necessidade de conter e controlar as reivindicações da sociedade relativamente ao Estado. Em breve, o diagnóstico da crise enquanto crise de governabilidade passou a ser dominante, o mesmo se verificando com a terapia política proposta pela Comissão Trilateral: do Estado central para a devolução/descentralização; do político para o técnico; da participação popular para sistemas de peritos; do público para o privado; do Estado para o mercado (Crozier et al., 1975). A década seguinte assistiu à construção de um novo regime político-social baseado nestas ideias e que em breve seria imposto à escala global sob a designação de Consenso de Washington. Foi uma década de profundas transformações político-ideológicas, que prepararam o caminho para o avanço da solução abrangente para a crise da governabilidade: a lei do mercado.

Enquanto a perspectiva da crise de legitimidade via a solução na transformação do Estado e no reforço da participação popular, através de movimentos sociais novos e autónomos, já sob o prisma da crise da governabilidade a solução estava na retracção do Estado (arredado da esfera económica e da prestação de serviços sociais) e na domesticação da participação popular (através de políticas restritivas de tal participação, por sua vez baseadas numa concepção individualista da sociedade civil dominada pelas organizações empresariais). Estas organizações, cuja pertença à sociedade civil se tornara problemática devido à crescente autonomia da sociedade civil republicana relativamente ao mercado, foram subrepticiamente reintroduzidas na sociedade civil através de um processo de dupla identificação, simultaneamente como agentes do mercado e como actores sociais. 
Por volta de 1986, tornou-se claro que todas as outras recomendações da Comissão Trilateral seriam aceites como "naturais" a partir do momento em que fossem aplicadas três regras fundamentais: a privatização, a "mercantilização" e a liberalização. Estas três grandes regras tornaram-se nos três pilares do neoliberalismo e da globalização neoliberal. A década seguinte (de 1986 a 1996) foi o ponto alto do neoliberalismo, com o Estado a retirar-se do sector social e da regulação económica, com a lei do mercado a presidir à regulação económica e social, e com a proliferação de organizações da sociedade civil, genericamente designadas por "terceiro sector", cuja finalidade consiste em satisfazer as necessidades humanas a que o mercado não consegue dar resposta e o Estado já não está em condições de satisfazer (Santos, 2002: 439-95; Santos e Jenson, 2000). Esse é também o período em que os fracassos do mercado, enquanto grande princípio da regulação social, se tornam evidentes. $\mathrm{O}$ enorme aumento da polarização dos rendimentos e dos níveis de riqueza, com o seu efeito devastador sobre a reprodução dos modos de subsistência de populações inteiras; o aumento generalizado da corrupção; os efeitos perversos da conjugação da lei do mercado com a democracia não-distributiva, conducente à implosão de alguns Estados e a guerras civis inter-étnicas - são, todos eles, factos com uma disseminação demasiado ampla e profunda para poderem ser descartados como meros desvios anómalos. Foi nesta conjuntura que a governação surgiu, enquanto matriz social e política nova.

Os últimos trinta anos podem, assim, resumir-se na seguinte sequência de conceitos: da legitimidade à governabilidade; da governabilidade à governação. Transpondo para a terminologia hegeliana, podemos pensar na governação como sendo a síntese, que supera a tese (a legitimidade) e a antítese (a governabilidade). Na verdade, a governação procura aliar a exigência de participação e de inclusão - reivindicada pela perspectiva que encara a crise social pelo lado da legitimidade - com a exigência de autonomia e de auto-regulação reivindicada pela perspectiva da governabilidade. Trata-se, todavia, de uma falsa síntese, uma vez que funciona totalmente dentro do quadro da governabilidade. Em vez de ressuscitar a procura de legitimidade que caracterizou a década de 1970, ela tenta reconstruir a governabilidade de maneira a transformá-la numa concepção alternativa da legitimidade.

\subsection{O significado político da governação neoliberal}

Para identificar o significado político da governação neoliberal, temos que prestar atenção não apenas àquilo que ela diz mas também àquilo que silencia. São os seguintes os silêncios mais importantes da matriz da gover- 
nação: as transformações sociais, a participação popular, o contrato social, a justiça social, as relações de poder, e a conflitualidade social. Foram estes os conceitos com que, na década de 1970, foi formulada a crise da legitimidade. Foram também os conceitos em que se alicerçou a teoria crítica moderna. Ao silenciá-los sem para eles oferecer uma alternativa positiva, a governação assinala a derrota da teoria crítica tanto no plano social como no plano político. De facto, as alternativas aos conceitos silenciados propostas pela governação são, todas elas, negativas, no sentido em que se definem por oposição aos conceitos da legitimidade: em vez de transformações sociais, a resolução de problemas; em vez da participação popular, participação dos titulares de interesses reconhecidos (stakebolders); em vez do contrato social, a auto-regulação; em vez da justiça social, jogos de soma positiva e políticas compensatórias; em vez de relações de poder, coordenação e parcerias; em vez de conflitualidade social, coesão social e estabilidade dos fluxos.

Estes conceitos alternativos não deixam de conter aspectos positivos. Com efeito, alguns deles reflectem certas aspirações da democracia avançada. São negativos na medida em que são utilizados em oposição aos outros conceitos silenciados, e não como uma componente complementar da mesma constelação política. Deste modo, em vez de estarem ao serviço de um projecto de inclusão social e de redistribuição social, estão, isso sim, ao serviço da exclusão social e da polarização económica.

No cerne da crise da legitimidade encontrava-se a ideia da soberania popular e da participação popular, alicerce da equação fundamental necessária a uma transformação social verdadeiramente capacitadora: não há benefício sem participação; e não há participação sem benefício. Tal equação decorre das seguintes premissas: o direito a determinar o benefício cabe a quem participa; a condição para uma tal autodeterminação é a autodeterminação da participação. A matriz da governação lida com esta equação de uma forma complexa. Ela aceita a equação na condição de substituir a participação autodeterminada por uma participação baseada num princípio de selecção segundo o qual apenas alguns actores, interesses ou vozes são admitidos a participar. A participação pode ser autónoma, mas não assim os critérios de escolha dos participantes. Pode haver benefício para os que são admitidos, mas sempre à custa da invisibilização dos preteridos. A equação é, assim, desenraizada e instrumentalizada. Se o princípio de selecção é posto em causa e os que não são admitidos ganham visibilidade, poderão eventualmente obter benefícios, mas sob a condição de não participarem. Se a natureza e o âmbito dos benefícios são postos em causa pelos participantes admitidos, estes poderão usufruir da possibilidade de continuar a 
participar, mas com a condição de não insistirem na autodeterminação dos respectivos benefícios. Em casos extremos, dir-se-á que o benefício reside na participação em si mesma.

Aplicando à governação a sociologia das ausências (Santos e Rodríguez-Garavito, 2005), é possível detectar dois actores não-existentes: o Estado e os excluídos. No caso do Estado, não é ele propriamente que está ausente; estão, sim, ausentes o princípio da soberania e o poder coercivo que lhe andam associados. O Estado é, portanto, um parceiro legítimo da governação, desde que participe numa qualidade que não a de Estado soberano e que, ao fazê-lo, assuma, idealmente, um estatuto semelhante ao dos demais parceiros. Mas a questão tem mais que se lhe diga. A passagem da legitimidade à governabilidade foi provocada pela incapacitação do Estado enquanto regulador social. No entanto, o Estado não foi privado do seu papel de meta-regulador, quer dizer, de entidade responsável por criar espaço para reguladores não-estatais legítimos. Será desnecessário dizer que este tipo de intervenção do Estado é bem diferente daquele que presidiu ao contrato social. No caso deste último, o Estado seleccionou dois actores sociais bem definidos - o capital e o trabalho - e trouxe-os à mesa das negociações, controlada pelo próprio Estado, procurando chegar a acordos passíveis de ser acompanhados e, se tal se afigurasse necessário, aplicados através da coerção estatal. A formação política assim gerada era uma formação de conflitos institucionalizados e não de fluxos estáveis; de coexistência pacífica e não de objectivos comuns.

É diversa a maneira como os excluídos são remetidos à não-existência. Não é possível obrigá-los simplesmente a ficar de fora, como sucedia no contrato social e no Estado providência, uma vez que, ao contrário deste, a matriz da governação não aceita o binómio dentro/fora. O que quer que fique de fora não é concebido como fonte de um poder capaz de transformar a exclusão em inclusão. Inclusão e exclusão são, desse modo, despolitizadas, não mais do que dimensões técnicas da coordenação. Na ausência de um comando soberano, a exclusão só existe como dilema da exclusão: como obter poder para lutar pela inclusão no círculo da governação, quando todo o poder que há decorre de se pertencer a esse círculo?

Algumas das vozes da teoria crítica do direito, incluindo eu próprio, vêm defendendo que a moderna juridificação da vida social - ou seja, a concepção segundo a qual as transformações sociais são uma luta por direitos cuja regulação é exercida pela democracia liberal e pelo Estado de direito - se traduziu num recuo da política, à medida que a protecção de um número crescente de interesses sociais foi passando a estar dependente de especialistas do direito dotados de uma mentalidade tecnicista, 
em vez de depender da mobilização e do peso político (Santos 1995, 2000, 2002). Numa comparação retrospectiva, o paradigma jurídico afigura-se agora como muito mais político do que a matriz da governação. Para os autores da área da teoria crítica, a despolitização provocada pelo direito foi uma opção altamente política, o mesmo se podendo dizer a propósito da governação.

É possível contestar a ideia, aqui defendida, de que a governação é a forma de governo do neoliberalismo assente no primado das leis do mercado, uma vez que todo o instrumentário conceptual, tanto ideológico como técnico, da governação vai contra aquele que subjaz à lógica do mercado. Em lugar de concorrência (mercado), coordenação e parceria (governação); em lugar de destruição criativa, problemas sociais; em lugar de rentabilidade, coesão social; em lugar de consequências imprevistas, consequências a tratar como se houvessem sido previstas; em lugar de mercado, sociedade civil. Em resumo, a matriz da governação surgiu para corrigir falhanços do mercado, sendo dominada por uma lógica que não é uma lógica económica mas sim uma lógica social. De facto, o período áureo do neoliberalismo assistiu ao crescimento exponencial de organizações da sociedade civil e de ONGs, muitas delas apostadas em oferecer algum alívio a populações desamparadas em consequência da progressiva extinção das redes de segurança outrora proporcionadas pelo Estado-Providência e agora incapazes de adquirir esse apoio no mercado.

O ressurgimento da sociedade civil durante as décadas de 1980 e 1990 é um fenómeno complexo, para o qual não existe uma explicação monocausal. A este respeito, distinguirei três processos distintos. O primeiro é constituído pelas organizações da sociedade civil (OSC) que surgiram na Europa Central e de Leste para reivindicar uma esfera pública não-estatal autónoma a partir da qual pudessem lutar contra os regimes autoritários do Estado socialista. Essas organizações foram muito influentes no período de transição democrática que se seguiu à queda dos regimes socialistas. Um tipo semelhante de sociedade civil surgiu em muitos países da América Latina durante o período de transição democrática que se seguiu à queda das ditaduras militares que vigoraram desde meados das décadas de 1960 ou 1970 até finais da década de 1980. Enquanto na Europa Central e de Leste as OSCs vieram pôr em causa o regime político e económico, na América Latina as OSCs puseram em causa o regime político autoritário, mas, de um modo geral, não se opuseram ao modelo económico implantado em concomitância com a democracia, isto é, o neoliberalismo. Quando as transições democráticas foram dadas por findas, a maioria dessas OSCs desapareceu, fosse porque passaram a partidos políticos ou a empresas de 
consultoria ou de representação de lóbis, fosse porque se reconverteram, encaixando assim no terceiro tipo de OSCs abaixo referido.

O segundo processo é o que mais estreitamente se relaciona com a crise da governabilidade, e consiste em OSCs que não se opuseram nem ao regime político (a democracia liberal) nem ao modelo económico (o capitalismo neoliberal), antes se considerando a si próprias como organizações de solidariedade vocacionadas para satisfazer as necessidades humanas das vítimas da reestruturação económica, da espoliação, da discriminação, da degradação ambiental, da guerra, das violações maciças dos direitos humanos, etc. Elas formam a parte maior do terceiro sector, ou o campo das ONGs. Ocupam-se do privado, não do público; do social, não do político; do micro, não do macro (a democracia liberal e o capitalismo neoliberal).

Por último, há, subjacente ao ressurgimento da sociedade civil, um terceiro processo a considerar. Nele se incluem as OSCs - muitas delas com origem nos novos movimentos sociais, tanto do Norte como do Sul - que lutam contra a globalização neoliberal. Embora muitas destas organizações prestem serviços similares aos das OSCs do segundo tipo, elas situam as suas acções num conceito de activismo político mais alargado. Põem em causa o modelo hegemónico de democracia, advogando uma democracia participativa de base. Recusam a ideia de que não existe alternativa à globalização neoliberal, consideram-se anticapitalistas, e advogam economias alternativas, modelos alternativos de desenvolvimento, ou alternativas ao próprio desenvolvimento. Não obstante terem, na sua maioria, uma implantação local, trabalham em rede com organizações semelhantes de outros espaços, bem como com organizações de âmbito global. São estes elos e toda esta ligação em rede, numa relação a um tempo local e global, que constituem a globalização contra-hegemónica.

A paisagem das OSCs é, por conseguinte, bastante rica e diversificada. Os diferentes processos que explicam o ressurgimento das OSCs nas décadas de 1980 e 1990 conduziram a dois tipos principais de sociedade civil: por um lado, a sociedade civil liberal, constituída pelas OSCs do primeiro tipo que descrevi acima; por outro lado, um segundo tipo de sociedade civil, subalterna e contra-hegemónica, constituída pelos movimentos sociais e pelas OSCs que mantêm em equilíbrio instável o macro e o micro, o público e o privado, o social e o político, centrando-se, para tanto, nas causas profundas do sofrimento humano que se propõem minorar. Estão empenhadas em criar esferas públicas não-estatais subalternas, tanto ao nível local como ao nível nacional e global.

Esta clivagem entre dois grandes tipos de sociedade civil explica a centralidade do princípio da selecção na matriz da governação. A sociedade 
civil admitida à participação na governação é a sociedade civil liberal, uma vez que só as suas organizações partilham os valores subjacentes à parceria e à coordenação auto-regulada. A resolução de problemas e a coesão social são mais fáceis de atingir quando a política e a ideologia não interferem na prossecução de objectivos e de interesses comuns. Só as concepções de interesses e de benefícios que se apresentem como abertas, fragmentárias e pragmáticas é que poderão ser inteligíveis para o mercado - esse mercado que é a mais flexível e esquiva de todas as instituições - e nele produzir impacto, contribuindo assim para que os mercados continuem florescentes, não obstante os seus gritantes fracassos.

À luz desta realidade, a governação neoliberal procede àquilo a que De Angelis (2003: 23) chama "a inversão de Polanyi". Enquanto Polanyi defendia que a economia existe incrustada na sociedade, a matriz da governação tem por premissa a necessidade de incrustar a sociedade na economia. Como afirma o pacto global das Nações Unidas, "a ideia é que o empenhamento numa cidadania empresarial deverá partir da própria organização, através da incrustação de princípios e valores universais na sua visão empresarial estratégica, bem como na sua estrutura organizativa, iniciativas culturais, e funcionamento diário" (UN, 2000: 3).

Por outras palavras, os "valores universais" são bons para o negócio, e nessa premissa reside o carácter voluntário do pacto (Shamir, 2005). Não existe qualquer possibilidade de esses valores ou princípios porem em perigo a perspectiva de lucro de que depende o florescimento das organizações económicas - como sucedeu, por exemplo, com os impostos quando surgiram pela primeira vez. Por serem compulsórias, as políticas públicas relativas a impostos acabaram por seleccionar as empresas capazes de sobreviver sob o regime de impostos. Na matriz da governação, pelo contrário, cabe às empresas seleccionar os valores e princípios com os quais se sentem capazes de funcionar.

Mesmo quando as empresas, coagidas pela pressão de activistas envolvidos em campanhas de publicidade negativa, concordam em pautar-se por códigos de conduta básicos, fazem-no por calculismo económico (e não por uma motivação social).

Em face de tudo isto, direi que a governação é uma forma geneticamente modificada de direito e de governo, que procura tornar-se resistente a duas perigosas pragas: por um lado, pressões populares, a partir de baixo, potencialmente caóticas; por outro lado, mudanças imprevisíveis das regras do jogo da acumulação de capital, causadas pela regulação estatal ou inter-estatal. 


\subsection{Lutas sociais no quadro da governação}

A relação histórica entre democracia e capitalismo é uma relação não-linear, quanto mais não seja porque, ao longo dos últimos duzentos anos, vigoraram diferentes modelos de democracia (Macpherson, 1966, 1977; Held, 1987) bem como diferentes modelos de capitalismo (Boyer, 1986; Boyer e Drache, 1996; Santos, 2001). Ao longo do século XX, a tensão entre democracia e capitalismo vivida no Norte girou em torno da questão da redistribuição social. Essa foi uma das grandes questões subjacentes à crise da legitimidade durante a década de 1970. A conversão da crise da legitimidade em crise da governabilidade foi a resposta capitalista às pressões no sentido de uma redistribuição social mais ampla e mais profunda. O neoliberalismo neutralizou, ou enfraqueceu grandemente, os mecanismos democráticos de redistribuição social - ou seja, os direitos socioeconómicos e o Estado providência. Privada do seu potencial redistributivo, a democracia tornou-se completamente compatível com o capitalismo, e em tal grau que ambos se transformaram nos conceitos gémeos que presidem ao novo modelo global das questões políticas e sociais, um modelo imposto a nível mundial pela globalização neoliberal, pelas políticas de ajustamento estrutural e também, mais recentemente, pela guerra neocolonial.

Passados trinta anos, a questão da redistribuição afigura-se mais séria do que nunca. Nalguns sectores da produção e nalgumas regiões do mundo, os índices de exploração atingiram níveis tão elevados que, a julgar também pelos mecanismos utilizados para os obter, parece estarmos a entrar numa nova época de acumulação primitiva do capital. Acresce que as populações não sujeitas à exploração ou insusceptíveis de o ser se encontram numa situação mais dramática ainda, porquanto as condições de manutenção dos respectivos modos de vida se foram deteriorando em resultado da reestruturação económica e da degradação ambiental; foram, por isso, declaradas populações descartáveis. Finalmente, a receita triádica formada pela privatização, mercantilização e liberalização desgastou aquilo que era propriedade comum tutelada pelo Estado, transformando-a numa nova geração de direitos privados. Surgiu uma nova forma de governo indirecto (ecoando o "indirect rule" do colonialismo inglês) em que actores económicos poderosos detêm um poder tremendo e desobrigado de qualquer responsabilidade, controlando desse modo os meios de subsistência básicos das pessoas, desde bens como a água até à energia, passando pelas sementes, pela segurança ou pela saúde.

A redistribuição social é o problema mais sério com que nos deparamos neste início do século XXI. Mas não é o único. Desde a década de 1980 que ao problema da redistribuição social veio juntar-se o problema do reconhe- 
cimento da diferença. Hoje em dia, vivemos em sociedades que são tremendamente desiguais, contudo a igualdade não é o único valor que prezamos. Também prezamos a diferença, o reconhecimento das diferenças sem hierarquia entre elas, aspiração que não teve uma presença vincada aquando da concepção da crise da legitimidade da década de 1970.

O verdadeiro teste para a governação é, por conseguinte, saber em que medida consegue fazer frente, quer à questão da redistribuição social, quer à questão do reconhecimento da diferença. À luz do que afirmo atrás, não considero que na matriz da governação seja gerado qualquer potencial para uma redistribuição social significativa. A governação está em melhores condições de dar resposta à questão do reconhecimento da diferença do que à questão da redistribuição social, mas mesmo aí se tornarão patentes as suas limitações estruturais.

Tal não quer dizer que as disposições da governação não produzam alguns benefícios para os grupos mais desfavorecidos incluídos no círculo de parceria. Esses benefícios poderão até, eventualmente, extravasar para os excluídos. Mas daí não advém nenhum potencial propício a uma participação popular capacitadora, ou a uma redistribuição social entendida como um direito próprio. Dito de outro modo, aquilo que é benéfico não determina, só por si, aquilo que é emancipatório. Se a população dos sem-abrigo aumenta exponencialmente, é bom que aqueles que possuem residência própria os deixem abrigar-se no alpendre das suas casas. Sempre é melhor do que nada. No entanto, devido ao carácter voluntário do gesto, a redistribuição assim obtida obedece à lógica da filantropia. Ou seja, ela não ocorre de uma forma capacitadora, em reconhecimento tanto do direito à habitação como do direito a reclamar a efectividade do direito à habitação de uma maneira autónoma e participativa.

Poderá dizer-se que, em determinadas circunstâncias, o carácter voluntário do acatamento é mais virtual do que real, e isso dadas as pressões exercidas - muitas vezes a partir de fora - sobre o círculo da governação. Neste caso, pode suceder que intervenham processos sociais diferentes, sendo, por isso, necessário fazer distinções analíticas e políticas. A título de ilustração, referir-me-ei sumariamente a dois exemplos de pressão externa provocada pelo Estado. O primeiro exemplo é retirado do estudo de César Rodríguez-Garavito (2005) sobre o funcionamento de códigos de conduta nas fábricas de confecções da Guatemala, laborando em condições de grande exploração da mão-de-obra (conhecidas por "maquilladoras" ou "sweatshops"). Durante o processo de negociações do Acordo Centro-Americano de Comércio Livre (CAFTA), o estado guatemalteco sofreu pressões do governo dos Estados Unidos da América no sentido 
de ser mais activo na repressão das violações dos direitos humanos no local de trabalho. Em risco de se ver excluído do CAFTA, o Estado guatemalteco, por sua vez, exerceu pressão sobre a marca de vestuário (Liz Claiborne) e respectivo fornecedor no sentido de respeitar o código de conduta daquela, facto que acabaria por permitir a sindicalização dos operários da fábrica. No segundo caso, analisado por Heinz Klug (2005), o Estado sul-africano, pressionado por um forte movimento social que exigia medicamentos anti-retrovirais gratuitos ou baratos para doentes com HIV/sida, conseguiu que, graças à sua própria pressão, as companhias farmacêuticas retirassem a queixa feita nos tribunais relativamente ao licenciamento obrigatório e à produção de genéricos e baixassem os preços dos seus produtos de marca.

Importa fazer notar que em ambos os casos o Estado, que se havia esquivado à regulação social, supostamente intervém a partir do exterior, usando - se não formalmente, pelo menos informalmente - da sua prerrogativa soberana de exercer pressão sobre o círculo da governação por forma a obter um determinado resultado considerado politicamente importante. Mas enquanto no caso da Guatemala o Estado intervém devido a uma pressão que vem de cima e os operários assim beneficiados não são chamados a participar na deliberação respeitante aos benefícios, no caso da África do Sul o Estado é pressionado a partir de baixo e cede à pressão das movimentações sociais. Com efeito, o Estado alia-se às movimentações sociais expressamente para essa finalidade. No primeiro caso, se os benefícios forem retirados aos operários, estes acabarão tão impotentes como estavam antes para os poderem reivindicar. No segundo caso, a acção do Estado contribui para conferir poder ao movimento social em causa, para lhe reforçar o papel de alavanca da contestação social numa situação específica e eventualmente também em casos futuros, inclusivamente contra o próprio Estado. Os dois casos, em suma, mostram que o Estado é a estrutura presente-ausente da matriz da governação - facto especialmente patente em condições de stress institucional -, o que significa que a matriz da governação funciona dentro da "auto-exterioridade" do Estado. Os casos relatados mostram ainda que, não obstante as condições desfavoráveis do presente, a luta capacitadora pelo direito à redistribuição - pelo direito a ter direitos, no dizer de Hannah Arendt (1968: 177) - poderá ter algum êxito, não devido à governação, mas sim apesar dela.

Antes de dar por findo este exame da matriz da governação, importa sublinhar que, não obstante eu questionar o facto de a governação se autocaracterizar como sendo pós-estatal, não é minha intenção defender um regresso às velhas formas de regulação estadocêntrica, que, de qualquer modo, 
estiveram sempre confinadas a um pequeno número de países, sobretudo europeus. Pelo contrário, é minha intenção propor uma nova forma de regulação que, sem prescindir da energia da sociedade civil (seja na sua forma liberal, seja na sua forma contra-hegemónica), atribui ao Estado nacional ou às instituições políticas democráticas supranacionais o papel estratégico de definir as desigualdades de poder existentes no interior do círculo da governação como problemas políticos que devem ser tratados em termos políticos. É sobre este tipo de legalidade e de governação que me debruçarei a seguir.

\subsection{Há outras histórias da governação?}

Nesta secção detive-me, até agora, na governação neoliberal. Pode até parecer que não há mais nada no horizonte. Mas há. Como ficou dito acima, recentemente, a globalização neoliberal, apesar de continuar a ser a forma dominante de globalização, foi confrontada com outra forma de globalização - a globalização contra-hegemónica. Nos últimos dez anos, e de um modo mais evidente a partir dos protestos de Seattle, aquando da reunião da OMC de 1999, tem-se assistido ao surgimento de outra forma de globalização resultante dos movimentos sociais e das organizações da sociedade civil que, através de ligações simultaneamente de tipo local e global, vêm empreendendo uma luta global contra todas as formas de opressão geradas ou intensificadas pela globalização neoliberal. Na secção que se segue centrar-me-ei sobre as condições políticas do surgimento de uma legalidade cosmopolita subalterna decorrente das práticas dos movimentos sociais e das ONGs agrupados no FSM. A minha tese é que no seio desta globalização contra-hegemónica alternativa está a ser gerada outra matriz de governação: uma governação contra-hegemónica insurgente, a qual implica a articulação e a coordenação entre uma imensa variedade de movimentos sociais e de organizações da sociedade civil, com a finalidade de combinar estratégias e tácticas, de definir agendas, e ainda de planear e levar a efeito acções colectivas.

Não deixa de ser surpreendente que os traços principais da governação neoliberal se encontrem também presentes na matriz da governação contra-hegemónica que subjaz ao Fórum Social Mundial: a participação voluntária, a horizontalidade, a coordenação, a parceria, a auto-regulação, etc. Diferentes percursos históricos levaram a esta surpreendente convergência. No que toca à governação neoliberal, o impulso dominante foi a rejeição do centralismo e da coerção estatais e a formulação de um novo modelo de regulação social baseado no reconhecimento selectivo dos interesses e na participação voluntária dos interessados. No que toca à governação contra-hegemónica, e como se mostra na secção a seguir, o impulso gerador foi, por um lado, a rejeição dos partidos operários e dos sindicatos como agen- 
tes históricos exclusivos e modos de organização privilegiados de uma transformação social de sentido progressista, e por outro lado a formulação de um novo modelo de emancipação social assente no reconhecimento da diversidade dos agentes da emancipação social e dos objectivos da transformação social.

Mais surpreendente ainda é o facto de a governação contra-hegemónica se defrontar com alguns dos desafios e dilemas que se colocam à governação neoliberal. Por exemplo, em ambos os casos funciona um princípio de selecção. No caso da governação contra-hegemónica, os grupos sociais mais excluídos, aqueles que seria de supor terem mais a lucrar com o êxito da luta contra a globalização neoliberal, não só não participam como têm poucas probabilidades de verem contemplados os respectivos interesses e aspirações. A utopia negativa que agrega todos os movimentos e ONGs - e que consiste na recusa da ideia de que não há alternativa à actual desordem capitalista global - coexiste com os diferentes e até contraditórios interesses, estratégias e agendas que os dividem. A luta pelo alargamento do círculo da governação contra-hegemónica continua, e alguns dos movimentos e ONGs que nela participam são os mesmos que lutam pelo alargamento do círculo da governação neoliberal.

Será que a governação neoliberal e a governação contra-hegemónica alguma vez se fundirão numa síntese dialéctica da governação global? Como adiante direi, é muito improvável que tal suceda. Será que se vão influenciar mutuamente? Tal é possível e, na verdade, já está a suceder, como resulta patente da análise do FSM, na secção que se segue.

\section{O Fórum Social Mundial como política e legalidade cosmopolita subalterna do Sul global 3}

\subsection{O FSM como política e legalidade cosmopolita subalterna}

O FSM constitui uma das mais consistentes manifestações de uma sociedade civil global contra-hegemónica e subalterna em vias de surgimento. Na sua definição mais ampla, o FSM é o conjunto de iniciativas de troca transnacional entre movimentos sociais e ONGs onde se articulam lutas sociais de âmbito local, nacional ou global, travadas (de acordo com a Carta de Princípios de Porto Alegre) contra todas as formas de opressão geradas ou agravadas pela globalização neoliberal.

Na prática, o FSM é o conjunto de fóruns - mundiais, temáticos, regionais, sub-regionais, nacionais, municipais e locais - que se organizam de

${ }^{3}$ A análise levada a cabo nesta secção está mais desenvolvida em Santos, 2005. 
acordo com a Carta de Princípios. O FSM não está confinado aos cinco encontros que tiveram lugar em Porto Alegre (Brasil), em 2001, 2002, 2003 e 2005, e em Mumbai (Índia) em 2004. Também inclui todos os outros fóruns que se reuniram paralelamente ao FSM. Em primeiro lugar, os fóruns temáticos como o Fórum das Autoridades Locais (quatro edições); o Fórum Parlamentar Mundial (cinco edições); o Fórum Mundial da Educação (três edições); o Fórum Mundial dos Juízes (três edições); o Fórum Mundial da Juventude (três edições); o Fórum da Diversidade Sexual. Em segundo lugar, inclui todos os fóruns que se têm realizado por iniciativa própria nos últimos três anos - fóruns nacionais, regionais e temáticos. Estes são em número demasiado grande para incluir numa lista completa. Entre os regionais, destacaria o Fórum Pan-Amazónico (duas edições), o Fórum Social Europeu (três edições), o Fórum Social Asiático, o Fórum Social Africano e o Fórum Social das Américas. Entre os fóruns temáticos, merecem uma menção especial o Fórum sobre "A Crise do Neo-Liberalismo na Argentina e os Desafios para o Movimento Global”, o primeiro fórum temático, organizado na Argentina em Agosto de 2002, o Fórum Temático Palestino sobre "Soluções Negociadas para Conflitos", em Dezembro de 2002 na cidade de Ramallah, e o Fórum sobre "Democracia, Direitos Humanos, Guerra e Tráfico de Droga", realizado na Colômbia em Junho de 2003. Em terceiro lugar, devem também ser incluídas no FSM as reuniões, nacionais ou internacionais, de movimentos ou organizações com vista à preparação dos fóruns acima citados. Finalmente, e apesar de a Carta de Princípios impedir o FSM de organizar acções colectivas em seu próprio nome, devem considerar-se como parte do processo do FSM as acções regionais ou globais levadas a cabo pelas redes de movimentos e organizações que integram o FSM, desde que essas iniciativas respeitem a Carta de Princípios. É o caso das acções aprovadas pela assembleia da Rede Global de Movimentos Sociais, que se reúne paralelamente ao FSM, e que, em meu entender, fazem parte do processo do FSM. Na assembleia que teve lugar durante o terceiro FSM, foi decidido convocar uma marcha global contra a guerra e pela paz em 15 de Fevereiro de 2003; na assembleia reunida durante o quarto FSM, decidiu-se igualmente convocar uma marcha global contra a guerra e pela paz, desta vez para 20 de Março de 2004, data do primeiro aniversário da invasão do Iraque. Estas acções colectivas são parte integrante do FSM, ainda que não sejam concretizadas em nome do FSM. ${ }^{4}$

\footnotetext{
${ }^{4}$ A inclusão destas acções no processo do FSM não é aceite por todos. O Conselho Internacional (CI) integra organizações cujos representantes no Conselho rejeitam qualquer relação orgânica entre o FSM e as acções aprovadas pela Rede Global de Movimentos Sociais ou por qualquer outra rede de movimentos ou organizações. Segundo esses representantes - dos quais se destaca Francisco
} 
O FSM é um novo fenómeno político. Não é aquilo a que se chama um evento, nem uma mera sucessão de eventos, ainda que procure conferir alguma dramatização às reuniões formais que promove. Não é um congresso académico, ainda que para lá confluam os contributos de muitos académicos. Não é um partido nem uma internacional de partidos, ainda que nele participem militantes e activistas de muitos partidos de todo o mundo. Não é uma ONG nem uma confederação de ONGs, ainda que a sua origem e organização devam muito às ONGs. Não é um movimento social, ainda que muitos dos participantes lhe chamem o movimento dos movimentos. Apesar de se apresentar como agente da mudança social, o FSM rejeita o conceito de um sujeito histórico privilegiado, o que equivale a dizer que não confere prioridade a nenhum actor social específico neste processo de mudança. Não obedece a nenhuma ideologia claramente definida, seja na definição do que rejeita, seja na daquilo que afirma.

As lutas sociais que encontram expressão no FSM não encaixam propriamente em nenhuma das duas grandes vias da mudança social sancionadas pela modernidade ocidental: a via da reforma e a via da revolução. Para além do consenso relativo à não-violência, as modalidades de luta a que recorre são extremamente diversas e perfilam-se ao longo de um eixo contínuo que vai desde a legalidade/institucionalismo até à acção directa/ insurreição. O próprio conceito de não-violência presta-se às interpretações mais díspares. Finalmente, o FSM não está estruturado segundo nenhum dos modelos da moderna organização política, quer se trate do centralismo democrático, da democracia representativa, ou da democracia participativa. Ninguém o representa nem está autorizado a falar - e muito menos a tomar decisões - em seu nome, se bem que se veja a si próprio como um fórum que viabiliza as decisões dos movimentos e organizações nele participantes 5 .

De seguida, começarei por dizer em que consiste a novidade política do FSM. Passarei depois a analisar os problemas e tensões criados por essa novidade, particularmente no que se refere à estratégia política e à acção política, bem como a sua relação com a acção institucional e o direito.

\footnotetext{
Whitaker, um dos fundadores do FSM (2003) - a abrangência e a inclusividade do FSM só podem ser preservadas se nenhuma acção em particular for atribuída ao FSM como um todo. Um debate recente sobre esta questão entre Francisco Whitaker, Bernard Cassen e eu próprio pode ser lido no Yearbook Global Civil Society 2005-06. Mais adiante, voltarei a esta questão.

${ }_{5}$ Para uma melhor compreensão do carácter político e dos objectivos do FSM, ver Sen et al. (2004). Ver também a Carta de Princípios (http://www.forumsocialmundial.org.br).
} 


\subsection{A novidade política do Fórum Social Mundial}

As inovações políticas do FSM podem ser formuladas do seguinte modo:

\subsubsection{Uma nova utopia crítica}

O FSM pressupõe o ressurgimento de uma utopia crítica, quer dizer, de uma crítica radical da realidade vigente, e a aspiração a uma sociedade melhor. Quando surge, apresenta-se como alternativa ao predomínio da utopia conservadora do neoliberalismo - isto é, da crença utópica segundo a qual o mercado não regulado é a fonte do bem-estar socioeconómico e a bitola pela qual devem ser aferidas (ou melhor: descartadas) as demais alternativas. Como todas as utopias conservadoras, o neoliberalismo distingue-se das utopias críticas pelo facto de se identificar com a realidade actual, de maneira que a sua dimensão utópica consiste na radicalização ou no pleno cumprimento do presente (Hinkelammert, 2002: 278).

A dimensão utópica do FSM consiste em afirmar a possibilidade de uma globalização contra-hegemónica. Assim, a utopia do FSM afirma-se mais em termos negativos (a definição daquilo que critica) do que em termos positivos (a definição daquilo a que aspira). Primeira utopia crítica do século XXI, o FSM visa romper com a tradição das utopias críticas da modernidade ocidental, muitas das quais redundaram em utopias conservadoras. O carácter aberto da dimensão utópica do FSM é a sua tentativa de fugir a esta perversão. Para o FSM, a exigência de alternativas é uma exigência plural. A afirmação de alternativas anda a par com a afirmação de que há alternativas às alternativas.

Acresce que a utopia do FSM é radicalmente democrática. O facto de o FSM se centrar nos processos de interacção entre os movimentos (e não na avaliação das agendas políticas destes) é a razão principal da sua coesão interna. Deste modo, ele contribui para maximizar aquilo que une e minimizar aquilo que divide. Este desígnio utópico, que de resto resulta claro da própria Carta de Princípios, visa promover consensos para além das clivagens ideológicas e políticas entre os movimentos e organizações participantes.

\subsubsection{Uma concepção muito ampla de poder e de opressão}

A globalização neoliberal não se limita a submeter ao mercado um número crescente de interacções, nem a aumentar a taxa de exploração dos trabalhadores através, por um lado, da transformação da força de trabalho em recurso global, e, por outro, dos obstáculos que cria à emergência de um mercado de trabalho global. A globalização neoliberal veio mostrar, com acrescida e brutal clareza, que a exploração está ligada a muitas outras 
formas de opressão que afectam mulheres, minorias étnicas (por vezes, maiorias), povos indígenas, camponeses, desempregados, trabalhadores do sector informal, imigrantes legais e ilegais, subclasses dos guetos urbanos, homossexuais e lésbicas, crianças e jovens sem futuro digno. Todas estas formas de poder e de opressão criam exclusão. Não se pode atribuir a uma delas, em abstracto, ou às práticas que lhe resistem, qualquer prioridade na reivindicação de que "outro mundo é possível”. As prioridades políticas estão sempre situadas e dependentes do contexto. Dependem das condições sociais e políticas concretas de cada país num dado momento histórico. Para responder a essas condições e às suas flutuações, os movimentos e organizações devem dar prioridade às articulações entre si. Isto explica, em última instância, a novidade organizacional de um FSM sem líderes, a sua rejeição das hierarquias e a importância que atribui às redes possibilitadas pela Internet (Waterman, 2003a, 2003b; Escobar, 2003).

\subsubsection{Equivalência entre os princípios da igualdade e do reconhecimento da diferença}

Vivemos em sociedades que são obscenamente desiguais e, no entanto, não nos basta a igualdade como um ideal emancipatório. A igualdade, entendida como equivalência entre o mesmo, acaba por excluir o que é diferente. Tudo o que é homogéneo no início tende a converter-se mais tarde em violência excludente. É aqui que reside a base da novidade política e organizacional mencionada atrás. Aqui reside também a base para a opção a favor da democracia participativa, enquanto princípio regulador da emancipação social, em detrimento de modelos fechados como o do socialismo de Estado.

\subsubsection{Privilegiar a revolta e o inconformismo em detrimento da revolução}

Não há uma teoria única para guiar estrategicamente os movimentos, pois o objectivo não é tanto conquistar o poder, mas antes transformar as muitas faces do poder tal como se apresentam nas instituições e nas sociabilidades. Além disso, mesmo aqueles para quem a prioridade é conquistar o poder estão divididos quanto à estratégia. Uns preferem rupturas radicais de modo a realizar uma nova ordem (revolução), enquanto outros preferem mudanças graduais por meio do compromisso e do diálogo com o inimigo (reforma). A este nível, a novidade consiste na celebração da diversidade e do pluralismo, na experimentação e também na democracia radical.

\subsection{Estratégia e acção política}

Dada a novidade política que esta utopia comporta, a sua tradução em planeamento estratégico e em acção política não pode deixar de se apre- 
sentar difícil. Tal tarefa está marcada pela trajectória histórica da esquerda política ao longo do século XX. A realidade das divergências é, muitas vezes, uma realidade fantasmática na qual as divergências sobre opções políticas concretas se misturam com divergências sobre os códigos e as linguagens em que essas opções se exprimem.

O FSM tem conseguido, até agora, superar as divergências políticas. Contrariamente ao que sucedeu com o pensamento e a prática de esquerda na modernidade capitalista ocidental, o FSM conseguiu criar um estilo e uma atmosfera de inclusão e de respeito em relação às divergências, um estilo e uma atmosfera que tornam bastante difícil que as diferentes facções políticas se auto-excluam sob o pretexto de estarem a ser excluídas. Para isso contribuiu decisivamente o programa "minimalista" do FSM declarado na sua Carta de Princípios: afirmação enfática do respeito pela diversidade; acesso quase incondicional (só estão excluídos os movimentos ou grupos que advogam a violência); ausência de votações ou de deliberações no Fórum enquanto tal; ausência de uma entidade representativa que fale em nome do Fórum. É quase semelhante a uma "tábua rasa" onde têm lugar todas as formas de luta contra o neoliberalismo e por uma sociedade mais justa. Perante uma tal abertura, aqueles que optam pela auto-exclusão sentem dificuldade em definir com rigor aquilo de que se estão a excluir.

Tudo isto contribuiu para tornar o poder de atracção do FSM maior do que a sua capacidade de repelir. Mesmo os movimentos que dirigem as mais severas críticas ao FSM, como os anarquistas, não têm estado ausentes. Existe, em definitivo, algo de novo no ar, algo que é caótico, confuso, ambíguo e suficientemente indefinido para merecer o benefício da dúvida. Poucos quererão perder este comboio, especialmente num tempo histórico em que os comboios deixaram de passar. Por todas estas razões, o desejo de salientar o que os movimentos e organizações têm em comum tem prevalecido sobre o desejo de sublinhar o que os separa. A manifestação de tensões ou de clivagens tem sido relativamente ténue e, acima de tudo, não tem resultado em exclusões mútuas. Teremos de esperar para ver quanto tempo irá durar esta vontade de convergência e esta partilha caótica de diferenças.

Nem os tipos de clivagens, nem o modo como os movimentos se relacionam com eles, estão aleatoriamente distribuídos dentro do FSM. Eles reflectem, pelo contrário, uma meta-clivagem entre as culturas políticas ocidentais e as não-ocidentais. Até certo ponto, esta meta-clivagem existe igualmente entre o Norte e o Sul. Assim, dada a forte presença de movimentos e organizações do Atlântico Norte e da América Latina branca, em particular nas três primeiras edições do FSM, não é de surpreender que as clivagens mais salientes espelhem a cultura política e a trajectória histórica 
da esquerda nessa zona do mundo. Isto significa, por um lado, que muitos movimentos e organizações de África, da Ásia, das Américas indígena e negra, e da Europa dos imigrantes, não se reconhecem nessas clivagens, e, por outro, que as clivagens alternativas que esses movimentos e organizações pretendem explicitar estão a ser ocultadas ou minimizadas pelas que são dominantes.

Depois desta advertência, o meu próximo passo será identificar as principais clivagens manifestas. No seu conjunto, elas representam o horizonte em que se desenrolam as possibilidades e as limitações da legalidade cosmopolita subalterna.

\subsubsection{Reforma ou revolução}

Esta clivagem carrega o peso da tradição da esquerda ocidental, apesar de poder ser encontrada noutras latitudes. É a clivagem entre os que pensam que um outro mundo é possível através da transformação gradual do mundo injusto em que vivemos, mediante reformas legais e mecanismos de democracia representativa, e os que pensam que o mundo em que vivemos é um mundo capitalista que nunca tolerará reformas capazes de questionar ou de perturbar a sua lógica de funcionamento, devendo, portanto, ser derrubado e substituído por um mundo socialista. Esta clivagem também é conhecida como dividindo moderados e radicais. Ambos os campos abrangem uma ampla variedade de posições. Entre os revolucionários, nomeadamente, há uma clivagem nítida entre a velha esquerda, que aspira a uma espécie de socialismo de Estado, os anarquistas, que são radicalmente anti-estatistas, e alguma da nova esquerda bastante ambivalente quanto ao papel do Estado numa sociedade socialista. Embora correspondam a uma proporção ínfima do FSM, os anarquistas situam-se entre os críticos mais ferozes do reformismo, que, segundo eles, controla a liderança do FSM.

A clivagem acima referida repercute-se, ainda que de forma não linear, nas opções estratégicas e nas escolhas de acção jurídica e política. No que à acção jurídica diz respeito, os reformistas mostram-se mais dispostos a incluir a mobilização jurídica e judicial nas suas lutas, desde que seja a mobilização política a definir o quadro da mobilização jurídica e não o contrário, ao passo que os revolucionários nutrem uma grande desconfiança pela lei, incluindo o direito informal implantado da base para o topo ou os direitos humanos internacionalmente reconhecidos. Segundo a sua perspectiva, existe entre a mobilização política e a mobilização jurídica uma profunda brecha (estratégica, mas também ideológica) que torna a articulação entre uma e outra praticamente impossível. A acção jurídica tende a individualizar os conflitos, a dar prioridade ao saber jurídico profissional, 
a furtar aos movimentos o ritmo próprio da luta, a inflacionar as pequenas conquistas reversíveis, vendo-as como grandes vitórias irreversíveis - tende, em suma, a ter um efeito desmobilizador. No que respeita às opções políticas mais concretas, uma das que mais ressaltam é a opção estratégica entre reformar/democratizar as instituições da globalização neoliberal (Organização Mundial do Comércio e instituições financeiras internacionais) ou lutar por eliminá-las e substituí-las.

O que é novo no FSM, enquanto entidade política, é o facto de a maioria dos movimentos e organizações que nele participam não se reconhecerem nestas clivagens e recusarem entrar nos debates sobre elas. Há uma enorme resistência a assumir rigidamente uma posição dada, e uma resistência ainda maior a rotulá-la de acordo com as ortodoxias taxonómicas do passado. A maioria dos movimentos e organizações têm experiências políticas nas quais momentos de confrontação alternam ou se combinam com momentos de diálogo e de compromisso, onde as visões de transformação social a longo prazo coexistem com as possibilidades tácticas da conjuntura social e política em que as lutas se desenrolam, onde as denúncias radicais do capitalismo não paralisam a energia para as pequenas mudanças quando as grandes não são possíveis, onde o recurso aos tribunais é considerado ora útil, ora prejudicial.

Acima de tudo, esta clivagem, para muitos movimentos e organizações, é ocidentalcêntrica ou nortecêntrica, e é mais útil para compreender o passado da esquerda do que para construir o seu futuro. Na verdade, uma parte dos movimentos e das organizações nem sequer se reconhece, pelas mesmas razões, na dicotomia entre esquerda e direita.

Precisamente pelo facto de que, para muitos movimentos e organizações, a prioridade não é conquistar o poder, mas transformar as relações de poder nas múltiplas faces da opressão, as tarefas políticas, por muito radicais que sejam, devem ser concretizadas aqui e agora, na sociedade onde vivemos. Portanto, não faz sentido perguntar a priori se o seu sucesso é incompatível com o capitalismo. O conceito de hegemonia de Gramsci é útil para compreendermos as acções políticas dos movimentos. O que é necessário é criar visões contra-hegemónicas alternativas, capazes de sustentar as práticas quotidianas e as sociabilidades de cidadãos e grupos sociais. O trabalho das lideranças dos movimentos é, naturalmente, importante, mas não deve ser, de modo algum, concebido como o trabalho de uma vanguarda iluminada que abre o caminho para as massas, sempre vítimas da mistificação e da falsa consciência. Pelo contrário, conforme o Subcomandante Marcos recomenda, cabe às lideranças "caminhar com aqueles que vão mais devagar". Para quem assim pense, a questão não é ter de escolher entre reforma ou 
revolução mas antes como alimentar, de modo sustentado, o inconformismo e a rebelião enquanto atitude subjectiva e prática política. Há ainda aqueles para quem a questão é conceber a revolução em sentido não-leninista, como uma questão de transformação civilizacional que se dilata por um longo período de tempo.

\subsubsection{Socialismo ou emancipação social}

Esta clivagem relaciona-se com a anterior, mas não há uma sobreposição total entre as duas. Independentemente da posição tomada em relação à clivagem anterior, ou da recusa em tomar posição, os movimentos e organizações divergem quanto à definição política do outro mundo possível. Para alguns, o socialismo ainda é uma designação adequada, por muitas e muito díspares que possam ser as concepções de socialismo. Para a maioria, porém, o socialismo transporta a ideia de um modelo fechado de sociedade futura, e deve, por isso, ser rejeitado. Preferem outras designações, menos carregadas politicamente, sugestivas de abertura e de uma busca constante de alternativas. Por exemplo, a emancipação social como a aspiração a uma sociedade em que as diferentes relações de poder sejam substituídas por relações de autoridade partilhada. Esta é uma designação mais inclusiva, e mais centrada em processos do que em estádios finais de transformação social. Aqueles que vêem as respectivas lutas em termos de emancipação social tendem a ter uma visão mais positiva da legalidade cosmopolita subalterna, baseada na circunstância de ao longo da história se registarem vitórias jurídicas e judiciais, hoje recordadas como marcos da emancipação social.

Mas muitos movimentos do Sul pensam que não é preciso colocar rótulos gerais nos objectivos e nas lutas. Os rótulos correm o risco de se afastar das práticas que os originaram, adquirindo uma vida própria e dando assim lugar a resultados perversos. Na realidade, segundo alguns, o conceito de socialismo é ocidentalcêntrico e nortecêntrico, sendo o conceito de emancipação igualmente presa da tendência ocidental para criar falsos universalismos. Daí que muitos não se reconheçam em qualquer dos termos desta dicotomia, e nem sequer se preocupem em propor uma que lhe seja alternativa.

\subsubsection{O Estado como inimigo ou como aliado potencial}

Esta é também uma clivagem em que os movimentos do Norte se reconhecem mais facilmente do que os movimentos do Sul. Por um lado, há aqueles que pensam que o Estado, apesar de no passado ter sido uma arena de luta importante, foi transnacionalizado e transformado num mero agente 
da globalização neoliberal durante os últimos 25 anos. Ou o Estado se tornou irrelevante, ou é hoje o que sempre foi: a expressão dos interesses gerais do capitalismo. O alvo privilegiado das lutas contra-hegemónicas deve ser, portanto, o Estado. E, quando assim não seja, as lutas devem ser travadas com total autonomia face ao Estado. Por outro lado, há aqueles que pensam que o Estado constitui uma relação social e é, enquanto tal, intrinsecamente contraditório, podendo ser utilizado como aliado em algumas lutas contra a opressão. Para esta posição, o Estado continua a ser uma importante arena de luta. A globalização neoliberal não retirou ao Estado a sua centralidade, apenas a reorientou para servir melhor os interesses do capital global. A desregulação é uma regulação social como qualquer outra, e, portanto, um campo político onde se deve agir se houver condições para isso.

A maioria dos movimentos, mesmo daqueles que reconhecem a existência de uma clivagem a este respeito, recusa tomar uma posição rígida e de princípio. As suas experiências de luta mostram que o Estado, sendo por vezes o inimigo, pode ser também um aliado precioso na luta contra as imposições transnacionais. Nessas circunstâncias, a atitude mais adequada é, uma vez mais, o pragmatismo. Se nalgumas situações a confrontação se justifica, noutras é aconselhável a colaboração. E noutras ainda é apropriada uma combinação das duas. O importante é que, em cada momento ou em cada luta, o movimento ou organização em questão seja claro e transparente nas razões para a opção adoptada, a fim de salvaguardar a autonomia da acção.

Também aqui a clivagem se prolonga, através dos modos como a mobilização jurídica pode fazer parte - ou não - das lutas contra-hegemónicas. A atitude pragmática relativamente ao Estado tende a ir de par com uma visão mais positiva do potencial progressista da acção jurídica e judicial. Ainda que nunca considere o Estado um seu aliado incondicional, esta posição abre-se à possibilidade de, em casos concretos, a institucionalização das disposições que corporizam a convergência entre a acção do Estado e os movimentos contra-hegemónicos poder ser benéfica para estes.

\subsubsection{Lutas nacionais ou lutas globais}

Esta é a clivagem mais uniformemente distribuída na totalidade dos movimentos e organizações abrangidos pelo FSM. Por um lado, há movimentos que, embora participem no FSM, acreditam que este não é mais do que um ponto de encontro e um acontecimento cultural, pois as verdadeiras lutas, que são realmente importantes para o bem-estar das populações, são travadas a nível nacional contra o Estado ou contra a sociedade civil nacional 
dominante. Como exemplo, num relatório sobre o FSM preparado pelo Movimento para a Democracia Nacional nas Filipinas, pode ler-se:

O Fórum Social Mundial continua a flutuar por cima, vendo e experimentando, mas sendo realmente incapaz de abordar as condições efectivas de pobreza e de privação de poder levadas a muitos países pela globalização imperialista. Se não encontrar formas definidas de traduzir ou até de transcender a sua "globalidade" em intervenções mais práticas que lidem com essas condições, poderá continuar a ser um fórum imenso, mas vazio, que constitui mais um evento cultural do que outra coisa qualquer. [...] As lutas nacionais contra a globalização são, e deveriam fornecer, a âncora para qualquer iniciativa de anti-globalização a nível internacional. (Gobrin-Morante, 2002: 19)

Por outro lado, há movimentos para os quais o Estado está hoje transnacionalizado e, por conseguinte, deixou de ser o centro privilegiado da decisão política. Este descentramento do Estado implicou também o descentramento da sociedade civil, que está hoje sujeita a muitos processos de globalização social e cultural. Além disso, nalgumas situações o objecto da luta (seja ele uma decisão da OMC, do Banco Mundial, ou a exploração de petróleo por uma empresa transnacional) está fora do espaço nacional e inclui uma pluralidade de países em simultâneo. É por isso que a escala da luta deve ser cada vez mais global, um facto em que o FSM baseia a sua relevância.

De acordo com a larga maioria dos movimentos, isto constitui, de novo, uma clivagem que não faz justiça às necessidades concretas das lutas concretas. O facto novo nas sociedades contemporâneas é que as escalas da sociabilidade - as escalas locais, nacionais e globais - estão cada vez mais interligadas. Na aldeia mais remota da Amazónia ou da Índia os efeitos da globalização hegemónica, e as formas como os Estados nacionais se comprometem com eles, são claramente sentidos. Se, em geral, isso acontece com as escalas da vida social e política, acontece ainda mais com as escalas das lutas contra-hegemónicas. No que aos movimentos participantes no FSM diz respeito, é evidente que, embora na organização de cada luta política ou social se privilegie uma determinada escala, seja ela local, nacional ou global, é condição para o êxito que as diversas escalas estejam envolvidas. A decisão que determina a escala a privilegiar é uma decisão política que deve ser tomada caso a caso.

O impacto desta clivagem na política do direito torna-se patente no peso relativo dado ao direito internacional, aos direitos humanos internacionais e à militância jurídica transnacional quando se faz o enquadramento das 
acções políticas. Sempre que os movimentos ou as ONGs encaram a mobilização jurídica como parte integrante da mobilização política, tendem a recorrer a estratégias jurídicas em diferentes escalas. Esse carácter trans-escalar faz parte integrante da legalidade cosmopolita subalterna - ou seja, o tipo de mobilização jurídica que, ao visar o global no local e o local no global, faz avançar a globalização contra-hegemónica (Santos, 2002: 468).

\subsubsection{Acção directa ou acção institucional}

Esta é a clivagem com o impacto mais imediato sobre a política do direito. É clara a sua ligação com as clivagens acima referidas, relativas à reforma/ revolução e ao papel do Estado. É, também, uma clivagem com uma longa tradição na esquerda ocidental. Aqueles para quem tal clivagem continua a ter uma grande importância são os mesmos que menosprezam a novidade da globalização neoliberal no processo histórico de dominação capitalista.

De um lado estão os movimentos que acreditam que as lutas legais, baseadas no diálogo e no compromisso com instituições do Estado ou agências internacionais, são ineficazes porque o sistema jurídico e político do Estado e as instituições do capitalismo são impermeáveis a quaisquer medidas legais ou institucionais capazes de melhorar efectivamente as condições de vida das classes populares. As lutas institucionais apelam à intervenção dos partidos, e estes tendem a colocar essas lutas ao serviço das suas clientelas e dos seus interesses partidários. O sucesso de uma luta institucional tem, pois, um preço elevado, o preço da cooptação, descaracterização e trivialização. Mas, mesmo nos casos raros em que uma luta institucional conduz a medidas legais e institucionais que correspondem aos objectivos dos movimentos, é quase certo que a aplicação concreta dessas medidas acaba por ficar sujeita à lógica jurídico-burocrática do Estado, frustrando assim as expectativas dos movimentos. É por isso que apenas a acção directa, o protesto de massa, as greves, garantem o sucesso das lutas. As classes populares não têm mais armas senão a pressão exterior sobre o sistema. Se elas não se arriscam, estão condenadas à partida.

Os apoiantes das lutas institucionais, pelo contrário, assumem que o "sistema" é contraditório, uma relação social e política em que é possível lutar e onde o fracasso não é o único resultado possível. Na modernidade, o Estado - e, mais concretamente, o direito do Estado - foi o centro desse sistema. No decurso do século XX, as classes populares conquistaram espaços jurídico-institucionais importantes, dos quais o sistema do Estado-Providência é uma boa manifestação. $O$ facto de o Estado-Providência estar 
hoje em crise, e de a "abertura" que ofereceu às classes populares estar actualmente a ser fechada, não significa que esse processo seja irreversível. $\mathrm{Na}$ verdade, não o será se os movimentos e organizações continuarem a lutar dentro das instituições e do sistema jurídico e judicial.

Em geral, os movimentos e organizações mais fortes são aqueles que privilegiam mais frequentemente as lutas institucionais, ao passo que os menos fortes são os que privilegiam com maior frequência a acção directa. Esta clivagem é mais acentuada nos movimentos e organizações do Norte do que nos do Sul. Contudo, a grande maioria dos movimentos recusa tomar partido nesta clivagem. Segundo eles, as condições jurídicas e políticas concretas devem ditar o tipo de luta a ser privilegiado. As condições podem, efectivamente, aconselhar o uso sequencial ou simultâneo dos dois tipos de luta. Historicamente, a acção directa esteve na génese de mudanças jurídico-institucionais de sentido progressista, e foi sempre necessário combater o aproveitamento ou mesmo a subversão dessas mudanças através da acção directa.

Apesar das diferenças, tanto os movimentos como as ONGs tendem, todos eles, a concordar que a mobilização jurídica exige um duplo investimento, um luxo a que a maioria deles não se pode dar. Por um lado, a escolha do fórum jurídico mais adequado requer, muitas vezes, recursos jurídico-financeiros com um custo proibitivo. Por outro lado, o tipo de activismo jurídico exigido - em que a um elevado nível de especialização jurídica há que aliar uma atitude política de sentido progressista, proporcionando o estímulo que procure ir além da decisão e da interpretação jurídica convencional - raramente se encontra disponível. Este facto explica por que razão os movimentos e ONGs mais fortes, frequentemente dotados de departamentos jurídicos próprios, tendem a possuir uma visão mais positiva da acção jurídico-institucional.

\subsection{O princípio da igualdade ou o princípio do respeito pela diferença}

Como já afirmei, uma das novidades do FSM é o facto de a larga maioria dos seus movimentos e organizações acreditar que, apesar de vivermos em sociedades obscenamente desiguais, a igualdade não é suficiente como princípio orientador da emancipação social. Esta emancipação deve basear-se em dois princípios: o princípio da igualdade e o princípio do respeito pela diferença. A luta por qualquer um deles deve ser articulada com a luta pelo outro, pois a realização de um é condição da realização do outro. Ainda assim, há uma clivagem entre movimentos e, por vezes, dentro do mesmo movimento, à volta da questão de saber se deve ser dada prioridade a algum 
destes princípios, e, nesse caso, a qual deles. Nos que respondem afirmativamente à primeira questão, a clivagem dá-se entre os que atribuem prioridade ao princípio da igualdade - pois só a igualdade pode criar oportunidades reais para o reconhecimento da diferença - e os que dão prioridade ao princípio do reconhecimento da diferença, pois sem esse reconhecimento a igualdade oculta as exclusões e marginalidades em que assenta, tornando-se assim duplamente opressiva (pelo que oculta e pelo que revela).

A clivagem ocorre entre movimentos e no interior do mesmo movimento. Atravessa, entre outros, os movimentos de trabalhadores, de negros, feministas e indígenas. Por exemplo, enquanto o movimento dos trabalhadores tem privilegiado o princípio da igualdade em detrimento do princípio do reconhecimento da diferença, o movimento feminista tem privilegiado este último em detrimento do primeiro. Mas, de facto, a posição mais partilhada - e mais vivamente advogada pelos movimentos indígenas - é que ambos os princípios têm prioridade em conjunto e que não é correcto dar prioridade a um deles em abstracto. As condições políticas concretas indicarão a cada movimento qual dos princípios deve ser privilegiado numa determinada luta concreta. Qualquer luta concebida sob a égide de um desses princípios deve ser organizada de maneira a abrir o espaço ao outro princípio.

No movimento feminista do FSM, esta posição é actualmente dominante. Virginia Vargas (s.d.) expressa-o bem quando afirma:

No Fórum Social Mundial, os feminismos começaram a [...] alimentar processos que integram a justiça de género com a justiça económica, recuperando ao mesmo tempo a subversão cultural e a subjectividade como estratégia de transformação de âmbito maior. Confrontam assim duas expressões amplas de injustiça: a injustiça sócio-económica, enraizada nas estruturas políticas e económicas da sociedade, e a injustiça cultural ou simbólica, enraizada nos padrões sociais de representação, interpretação e comunicação. Ambas as injustiças afectam as mulheres e as muitas outras vítimas de outras discriminações (por motivos raciais, étnicos, de orientação sexual, e até geográficos).

Vargas apela a novos feminismos - feminismos dos novos tempos - como um panorama discursivo, expansivo e heterogéneo, produzindo campos policêntricos de acção que se disseminam por um leque vasto de organizações da sociedade civil, muitas das quais não se dedicam exclusivamente à luta contra a discriminação sexual. E conclui: "A nossa presença no FSM, fazendo estas mesmas perguntas, é também uma expressão dessa mudança”. 
A coexistência dinâmica do princípio da igualdade e do princípio do reconhecimento da diferença tem um grande peso na definição da posição das políticas da legalidade nas lutas cosmopolitas subalternas. A crise tanto do reformismo demoliberal como do reformismo socialista teve o seu impacto mais directo no princípio da igualdade, que em verdade havia facultado toda a justificação para as lutas reformistas progressistas do século XX (Santos, 2002: 441). A crise não atingiu do mesmo modo o princípio do reconhecimento da diferença, podendo até afirmar-se que, paralelamente ao agudizar da crise do princípio da igualdade, se obtiveram importantes vitórias no que se refere à validação social do princípio do reconhecimento da diferença, como se pode ver sobretudo pelos movimentos feministas desencadeados a partir da década de 1970 e pelos movimentos indígenas verificados a partir da década de 1980. Estas vitórias vieram injectar uma credibilidade nova na política do direito tanto no Norte como no Sul, credibilidade propensa a extravasar para outras áreas da luta política.

\subsubsection{Transconflitualidade}

Muitas das tensões e clivagens acima referidas não são exclusivas do FSM. De facto, fazem parte do legado histórico das forças sociais que, ao longo dos últimos 200 anos, lutaram contra o status quo por uma sociedade melhor. A especificidade do FSM reside na circunstância de no seu seio coexistirem todas estas clivagens sem que isso perturbe o seu poder agregador. A meu ver, três factores contribuem para este facto. Em primeiro lugar, as clivagens são importantes de maneiras diferentes para os diferentes movimentos e organizações, e nenhuma delas está presente nas práticas ou nos discursos da totalidade dos movimentos e organizações. Deste modo, ao mesmo tempo que tendem para o fraccionismo, todos eles libertam um potencial para o consenso. Por outras palavras, todos os movimentos e organizações dispõem de um espaço para a acção e para o discurso que lhes permite pôr-se de acordo com todos os outros movimentos ou organizações, independentemente das clivagens que os atravessam. Em segundo lugar, não houve, até ao momento, qualquer exigência táctica ou estratégica susceptível de radicalizar as posições, intensificando, dessa forma, as clivagens. Pelo contrário, as clivagens têm sido de baixa intensidade. No que aos movimentos e organizações em geral diz respeito, tem sido mais importante aquilo que une do que aquilo que divide. Em terceiro lugar, mesmo quando se admitem clivagens, os diferentes movimentos e organizações distribuem-se, nessas suas diferenças, de uma maneira não linear. Se um dado movimento se opõe a outro numa dada clivagem, pode bem suceder 
acharem-se ambos do mesmo lado a propósito de outra clivagem. Assim, as diferentes alianças estratégicas ou as acções comuns prosseguidas por cada movimento tendem a contar com parceiros diferentes. Desta forma, excluem-se à partida a acumulação e o aprofundamento de divergências que poderiam resultar do facto de os movimentos se alinharem ao longo de clivagens múltiplas. Muito pelo contrário, as clivagens acabam, assim, por se neutralizar umas às outras. É é nesta transconflitualidade que reside, a meu ver, o poder agregador do FSM.

\section{A política do direito e da legalidade num contexto de globalizações conflituantes entre si}

Descrevi o FSM como sendo uma utopia realista de tipo crítico. Chegados aqui, impõe-se perguntar que tipo de relação entre o direito e a política (ou seja, aquilo que designo por política do direito) será congruente com esta utopia e a que estratégias políticas tem vindo a dar origem. Será que engloba uma utopia jurídica? Em que será comparável à governação neoliberal, essa forma jurídica privilegiada da globalização hegemónica?

Sustentei, noutro local, que a transformação oitocentista da moderna ideia de progresso na ideia de uma repetição infinita e sempre crescente da sociedade burguesa confiou tanto à moderna ciência (e em particular às ciências sociais) como ao direito a tarefa de descobrir e assegurar as regularidades da vida social e da transformação social que tornavam possível a "mudança normal" (Santos, 2002: 71-82). O direito, entretanto reduzido a direito do Estado, achava-se disponível, quer como instrumento para o cumprimento dos imperativos da regulação social, quer como pré-compreensão do conhecimento científico da sociedade ainda a desenvolver.

Essa disponibilidade ilimitada para a engenharia social por parte do direito do Estado esteve na raiz da sua conversão numa utopia própria - uma utopia jurídica. Esta utopia jurídica foi o motor de impulsão da mudança normal - isto é, da ideia de que, através de uma dialéctica de melhoria e repetição, a mudança social era um processo contínuo que avançava por transformações graduais sancionadas pelo direito estatal, o qual por sua vez ia também mudando de forma contínua e gradual.

Este padrão da mudança normal assenta nos seguintes pressupostos. Em primeiro lugar, por mais diversa que seja a sua aplicação concreta de Estado para Estado, o padrão da mudança normal não é senão a lógica política transnacional do sistema interestatal. Em segundo lugar, os mecanismos nacionais de administração desenvolvidos e montados pelo Estado encontram-se disponíveis e mostram-se eficazes em todo o território nacional, cujas fron- 
teiras são igualmente garantidas pelo Estado. Em terceiro lugar, a capacidade financeira do Estado para pôr em prática todas as suas estratégias depende, acima de tudo, da sustentabilidade do crescimento económico e, portanto, do êxito das estratégias de acumulação. Em quarto lugar, as aspirações humanas e o bem-estar das pessoas podem ser satisfeitos ou assegurados por produtos e serviços produzidos em massa e concebidos como mercadorias, mesmo não sendo distribuídos através dos mercados das mercadorias. Em quinto lugar, os riscos e perigos dos quais o Estado é chamado a proteger os seus cidadãos têm uma ocorrência rara, além de que são, maioritariamente, de pequena ou média gravidade.

Esta utopia jurídica está a atravessar uma crise profunda (e terminal?) que teve início nos primeiros anos da década de 1970 e se prolonga até aos dias de hoje (Santos, 2002: 71-82, 447-58). É na sombra (se não entre as ruínas) desta utopia jurídica e da respectiva crise que tanto a governação neoliberal como a legalidade cosmopolita subalterna devem ser entendidas. Elas representam duas interpretações contrastantes das condições resultantes da crise da moderna utopia jurídica, oferecendo, consequentemente, duas leituras prospectivas igualmente contrastantes daquilo que é este nosso tempo. A governação neoliberal vê a crise da utopia jurídica, não como problema, mas como solução. Segundo a matriz da governação, a moderna utopia jurídica é parte indissociável de uma ordem burocrática baseada no comando e no controlo, centrada no Estado e no aparelho judicial, e que, para além de autoritária, rígida e não participativa, está eivada de ineficácia e marcada pelo fosso entre a criação e a aplicação das leis (Simon, 2003). As características da governação acima referidas visam, assim, oferecer a solução para os problemas gerados pela moderna utopia jurídica, não pela sua crise.

Para a legalidade cosmopolita subalterna, a moderna utopia jurídica constituía uma falsa solução para o problema muito real que era gerir as tensões entre a democracia e o capitalismo. De um lado, as lutas democráticas pela inclusão no contrato social, que tiveram como resultado o alargamento dos direitos, uma certa redistribuição social e o aumento das interacções não-mercantis entre os cidadãos, possibilitadas pelo Estado-Providência. Do outro lado, o capitalismo mais a sua fixação no lucro e a sua visão da redistribuição social como uma forma de expropriação. A moderna utopia jurídica nunca achou maneira de resolver a contradição entre a democracia redistributiva e o capitalismo, no entanto manteve-a dentro de limites controláveis, estabelecendo assim os alicerces para as políticas de consenso que governaram os países centrais desde o período posterior à segunda Guerra Mundial até aos finais da década de 1960. 
A crise da utopia jurídica veio piorar o problema da redistribuição social. Paradoxalmente, fê-lo de maneira tal que as contradições entre democracia e capitalismo parecem ter-se desvanecido. Privada do seu potencial redistributivo, a democracia é hoje globalmente promovida pelos mesmos agentes que promovem o capitalismo pelo mundo fora. A tensão dissolveu-se numa complementaridade.

A questão, porém, tem mais que se lhe diga, pois falta referir essa disjunção profunda entre regime político e regime social, a que chamei fascismo social (Santos, 2002: 453, 2003). Trata-se de uma nova constelação sociopolítica caracterizada pelo confinamento da democracia a um campo político cada vez mais estreitamente definido e que coexiste (mais do que interfere) com certas formas de sociabilidade, em que os actores não-estatais mais poderosos assumem o poder de veto sobre a vida e o bem-estar dos actores menos poderosos ou daqueles desprovidos de qualquer poder. É uma constelação política altamente instável, reproduzida, nos países centrais, por uma transformação até aqui eficaz das políticas de consenso em políticas de resignação e, nos países periféricos, pela imposição de políticas de ajustamento estrutural frequentemente associadas à colaboração de elites locais corruptas. Fascismo social a uma escala global, eis o problema com que a legalidade cosmopolita subalterna se vê confrontada. De nada vale tentar reavivar a moderna utopia jurídica ou inventar uma nova.

A solução está numa utopia realista crítica cujo evoluir pragmático possa envolver a mobilização jurídica enquanto parte de um mobilização política de tipo mais amplo.

Para ser mobilizado com êxito num contexto contra-hegemónico, o direito tem de ser submetido a um profundo processo de revisão. Em causa está, antes de mais, a pergunta pela possibilidade do uso contra-hegemónico de um instrumento hegemónico como é o direito. Em segundo lugar, há que perguntar também pelas tradições contra-hegemónicas do direito e da legalidade e pela possibilidade da sua mobilização em lutas contra-hegemónicas. Como defendi de início, este des-pensar do direito implica um alargamento da concepção da política do direito e da legalidade. As lutas jurídicas levadas a cabo pela acção combinada dos movimentos e ONGs pertencentes ao FSM dão testemunho da necessidade de um tal alargamento. Fiz questão de sublinhar a diversidade interna do FSM salientando as principais clivagens existentes entre os diversos movimentos, o que por si só deveria bastar para nos pôr de sobreaviso quanto à ideia de que estamos a assistir ao surgimento de um novo paradigma. O que podemos afirmar é que, não obstante todas essas diferenças, eles têm em comum a procura do 
alargamento quádruplo da política da legalidade que é referido na secção introdutória.

Em primeiro lugar, a legalidade cosmopolita subalterna nunca é formulada como sendo uma estratégia jurídica, mas antes como uma estratégia política que engloba uma componente jurídica. Além disso, as lutas não se centram exclusivamente no princípio da igualdade (a redistribuição social), como sucedia com a moderna utopia jurídica, mas centram-se antes num equilíbrio complexo e dinâmico entre o princípio da igualdade e o princípio do reconhecimento da diferença.

Em segundo lugar, sempre que há o recurso ao direito, pode não ser necessariamente ao direito do Estado-nação; ou seja, pode também recorrer-se ao direito não-oficial local, bem como ao direito internacional ou transnacional. Nisto reside a natureza trans-escalar da mobilização jurídica. A diferença da legalidade cosmopolita subalterna relativamente à moderna utopia jurídica resulta evidente, porquanto esta se centrava exclusivamente no direito estatal oficial.

Em terceiro lugar, os saberes jurídicos susceptíveis de ser mobilizados no âmbito das lutas jurídicas cosmopolitas subalternas são bastante variados. É raro as lutas apoiarem-se exclusivamente no saber jurídico profissional avalizado pelo Estado. Povos indígenas, habitantes de bairros de lata, operários sobre-explorados em "sweatshops" ou "maquilladoras", camponeses sem terra e camponeses em luta por manter a posse tradicional da terra contra os regimes de propriedade ditados pelo mercado, mulheres discriminadas, minorias, grupos religiosos e castas inferiores, trabalhadores migrantes e trabalhadores da economia informal, ambientalistas e activistas pela paz - todos agem no pressuposto de que o direito é coisa estranha, composta por ingredientes diferentes em diferentes porções, que há que transportar em recipientes diferentes e usar (ou descartar) de diferentes modos, ao longo da estrada que nos há-de levar a uma sociedade mais justa.

Em quarto lugar, a prioridade da mobilização política sobre a mobilização jurídica e a diversidade de instrumentos políticos a que se recorre são consentâneas com uma concepção de luta social cujo quadro temporal é muito mais complexo do que aquele que presidiu à mobilização jurídica sob a égide da moderna utopia jurídica. Por um lado, os grupos sociais envolvidos nas lutas contra-hegemónicas recusam-se a ser vistos como residuais, inferiores, ignorantes, improdutivos, ou como tendo uma implantação apenas local. Por outro lado, recusam-se a esquecer que a longa duração do capitalismo e do colonialismo é um factor explicativo tanto das suas queixas como da sua resistência. 
Em suma, o FSM está nos antípodas da utopia jurídica presente no cerne das sociedades capitalistas modernas. No entanto, as lutas da globalização contra-hegemónica, cientes do risco que seria deitar fora o bebé com a água do banho, não podem dar-se ao luxo de não fazer uso de todos os meios não violentos ao seu alcance para combater a modernidade capitalista, incluindo os que foram inventados pela modernidade capitalista para trair as suas próprias promessas de liberdade, igualdade e não discriminação. Nisto reside uma concepção transmoderna do direito.

\section{Referências Bibliográficas}

Angelis, Massimo de (2003), "Neoliberal Governance, Reproduction and Accumulation", The Commoner, 7, 1-27.

Arendt, Hannah (1968), The Origins of Totalitarism. New York: Harcourt Brace Jovanovich.

Boyer, Robert (1986), Capitalismes fin de siècle. Paris: Maspero.

Boyer, Robert; Drache, Daniel (orgs.) (1996), States against Markets: The Limits of Globalization. New York: Routledge.

Castells, Manuel (1996), The Rise of the Network Society. Cambridge: Blackwell.

Crozier, Michel; Huntington, Samuel; Watanuki, Joji (1975), The Crisis of Democracy: Report on the Governability of Democracies to the Trilateral Commission. New York: New York UP.

Escobar, Arturo (2003), "Other Worlds Are (already) Possible: Cyber-Internationalism and Post-Capitalist Cultures". Comunicação apresentada no Painel "Cyberspace, Life after Capitalism Programme", $3^{\circ}$ Fórum Social Mundial, Porto Alegre, 23-28 de Janeiro.

Gobrin-Morante, C. (2002), "The World Social Forum Fights Imperialist Globalization", in L. Nisula; K. Sehm-Patomäki (orgs.), We, the Peoples of the World Social Forum. Network Institute for Global Democratization, Discussion Paper 2/2002, 19-21.

Habermas, Jürgen (1982), Theorie des kommunikativen Handelns. Frankfurt/M.: Suhrkamp.

Held, David (1987), Models of Democracy. Cambridge: Polity.

Hinkelammert, Franz (2002), Crítica de la razón utópica. Bilbau: Desclée de Brouwer.

Jessop, Bob (1998), "The Rise of Governance and the Risks of Failure: The Case of Economic Development”, International Science Journal, 155, 29-45.

Klug, Heinz (2005), "Campaigning for Life: Building a New Transnational Solidarity in the Face of HIV/AIDS and TRIPS", in Boaventura de Sousa Santos; César Rodríguez-Garavito, Law and Globalization from Below. Towards a Cosmopolitan Legality. Cambridge: Cambridge UP, 118-139.

Kuhn, Thomas (1970), The Structure of Scientific Revolutions. Chicago: University of Chicago Press. 
Macpherson, C. B. (1966), The Real World of Democracy. Oxford: Clarendon.

Macpherson, C. B. (1977), The Life and Times of Liberal Democracy. Oxford: Oxford UP.

Monedero, Juan Carlos (2003), La trampa de la gobernanza: Nuevas formas de participación política. Mexico: Cámara de Diputados.

Offe, Claus (1985), Disorganized Capitalism. Oxford: Polity Press.

Rodríguez-Garavito, César; Arenas, Luís Carlos (2005), “Indigenous Rights, Transnational Activism, and Legal Mobilization: The Struggle of the U'wa People in Colombia", in Boaventura de Sousa Santos; César Rodríguez-Garavito, Law and Globalization from Below. Towards a Cosmopolitan Legality. Cambridge: Cambridge UP, 241-266.

Rodríguez-Garavito, César (2005), "Global Governance, Cross-Border Organizing, and Labor Rights: Codes of Conduct and Anti-Sweatshop Struggles in Global Apparel Factories in Mexico and Guatemala", Politics E Society, 33.

Santos, Boaventura de Sousa (1995), Toward a New Common Sense: Law, Science and Politics in the Paradigmatic Transition. New York: Routledge.

Santos, Boaventura de Sousa (2000), A crítica da razão indolente: contra o desperdício da experiência. Porto: Afrontamento

Santos, Boaventura de Sousa (org.) (2001), Globalização: Fatalidade ou utopia?. Porto: Afrontamento.

Santos, Boaventura de Sousa (2002), Toward a New Legal Common Sense. London: Butterworths.

Santos, Boaventura de Sousa (2003), "Poderá o direito ser emancipatório?”, Revista Crítica de Ciências Sociais, 65, 3-76.

Santos, Boaventura de Sousa (2004), "A Critique of Lazy Reason: Against the Waste of Experience”, in Immanuel Wallerstein (org.), The Modern World System in the Longue Durée. New York: Free Press.

Santos, Boaventura de Sousa (2005), O Fórum Social Mundial: Manual de uso. Porto: Afrontamento.

Santos, Boaventura de Sousa; Jenson, Jane (orgs) (2000), Globalizing Institutions: Case studies in Regulation and Innovation. Aldershot: Ashgate.

Santos, Boaventura de Sousa; Rodríguez-Garavito, César (2005), "Law, Politics, and the Subaltern in Counter-Hegemonic Globalization”, in Boaventura de Sousa Santos; César Rodríguez-Garavito, Law and Globalization from Below. Towards a Cosmopolitan Legality. Cambridge: Cambridge UP, 1-26.

Sen, Jai (2004), World Social Forum. Challenging Empires. New Delhi: The Viveka Foundation.

Shamir, Ronen (2005), "Corporate Social Responsibility: A Case of Hegemony and Counter-Hegemony”, in Boaventura de Sousa Santos; César Rodríguez-Garavito, Law and Globalization from Below. Towards a Cosmopolitan Legality. Cambridge: Cambridge UP, 92-117. 
Simon, William (2003), "Solving Problems v. Claiming Rights: The Pragmatist Challenge to Legal Liberalism”, Pub. Law Research Paper, no 03-58, Stanford Law School; Columbia University - Columbia Law School.

United Nations (2000), Global Compact Primer. New York: United Nations (www. unglobalcompact.org).

Vargas, Virginia (s/d), Los aportes y los retos feministas en el Foro Social Mundial (http:// www.alainet.org/publica/retosfem/aportes.html).

Waterman, Peter (2003a), First Reflections on the World Social Forum, Porto Alegre, Brazil. Library of Alternatives, WSF (www.forumsocialmundial.org.br).

Waterman, Peter (2003b), Second Thoughts on the WSF: Place, Space and the Reinvention of Social Emancipation on a Global Scale. Library of Alternatives, WSF (www.forumsocialmundial.org.br).

Yearbook (2005-2006), Yearbook Global Civil Society 2005-06. London: Centre for the Study of Global Governance. 